\title{
Demarketing: A Tool for Managing Youth Vices in Tertiary Institution for National Development
}

\author{
Dr (Mrs) Olowe, Modupe Oluwatoyin ${ }^{1 *}$, Ayeni, Olapade Grace ${ }^{2}$ \\ ${ }^{1}$ Department of Business Education, Bamidele Olumilua University of Education, Science and Technology, \\ Ikere- Ekiti, Ekiti State, Nigeria. \\ ${ }^{2}$ Department of Business Administration, Bamidele Olumilua University of Education, Science and Technology, \\ Ikere- Ekiti, Ekiti State, Nigeria.
}

*Corresponding Author: Dr (Mrs) Olowe, Modupe Oluwatoyin, Department of Business Education, Bamidele Olumilua University of Education, Science and Technology, Ikere- Ekiti, Ekiti State, Nigeria.

\begin{abstract}
Marketing played a key role in the dawn of exponential growth and development of a nation. Marketing aims to increase sales and attains this goal by product assortment, new forms of consumer credit, positioning, guerilla, geographic growth and many other various tactics. Demarketing on the other hand represents the use of marketing techniques, as it is considered a complementary part of ordinary marketing, to influence customers into changing their attitude and behaviour towards specific products and services, by using the elements of marketing (the product, prices, distribution, and advertising) as effective tools to establish demarketing strategy. Demarketing of some products is necessary because there are some products that support vices in the youth. This study focuses on demarketing as a tool to managing youth vices in tertiary institution for national development, Specifically, the study highlights the theory backing up youth vices, concept of demarketing was discussed, types of demarketing and vices among the youth was highlighted. Demarketing strategies was discussed by the researcher. The paper concludes and suggested among others that, government should do wide broadcast by condemning the dangerous products that the youth uses and they should have a regular seminars and conferences with the trade unions condemning the productions and sales of such products and also parents should be a good example to the youth and be at a close watch on them.
\end{abstract}

Keywords: Demarketing, Strategy Managing Youth, Youth Vices, National Development

\section{INTRODUCTION}

Tertiary institution is referred to as a third stage, third level, and post-secondary education; it consists of universities, polytechnics, monotechnics, and colleges of education. The objectives of tertiary institution is to train minds and soul, giving the students wisdom and knowledge, giving out guiding principle to social order, training to have love for higher values of life, training the youth to be leaders of tomorrow, also making them to be self-reliant and self-sufficient in their choice of career, all the training were gear up to national development, youth forms the population of students at this level of education (Wikipedia, 2017).

Youths are part of the agent of national development, the youths are the ones that will hold the country in the future, and at present they are very important in the society. Young people play a crucial role in the prospect for development and should be included in all national development plans and programme (Kabir, 2008), unfortunately, in Nigeria tertiary institution there are different social vices that could be found among theyouths, such as, gambling, prostitution, gluttony, smoking, using drugs, social networking, sexual abuse, examination malpractices, cultism, inordinate ambition, indecent dressing and some others. Materials been used for all these activities were bought in the market through the marketers, the invention of marketing is to take products to the final consumers. They satisfied the needs of the consumers. Marketing is the activities gear towards creating, communicating, delivering and exchanging offerings that have values for customers. The marketers also have the power to discourage purchases of some products and this strategy is demarkerting.

Demarketing is an aspect of social marketing, as its philosophy is based on creating a better healthier environment for the community as it represents an important tool to determine the consumption of a 
certain product permanently or temporarily (Shilpa, Pise, Sreedhar, \& Udupa, 2007). Demarketing represents the use of marketing techniques, as it is considered a complementary part ofordinary marketing, to influence customers into changing their attitude and behaviour towards specific products and services, by using the elements of marketing (the product, prices, distribution, andadvertising) as effective too is to establish demarketing Strategy. According to Samydai (2017), demarketing is considered as an important tool to be used to limit demand and consumption of certain products or services permanently or temporarily. It represent the use of marketing techniques to influence customers into changing their attitude and behavior towards specific products and services. Philips and Sidney (2019) coined demarketing as the efforts made by a company to reduce consumption of a product.

\section{OBJECTIVE OF The STUdY}

This study focuses on the demarketing- a tool for managing youth vices in tertiary institution for national development, specifically it will highlight the strategies of reducing consumption, by decreasing offer and limiting promotional activities of such products which will be reflected by reducing the product image in the mind of the customers.

\subsection{Theoretical Framework}

\subsubsection{The Social Learning Theory}

Social learning is the most common way that people learn. Therefore, it has important implications for curbing adolescent's drug addiction. The social interactions that have the greatest influence on adolescents are with the people who mattered to them as they grow up. This includes parents and other family members. It might also include a neighbor or teacher. Maybe they noticed their parents only ever relaxed and had fun when they gambled (perhaps playing cards with friends). Maybe they coped with stress by smoking pot. Maybe they observed they never socialized unless they were drinking. If they observed these sorts of things, then they might likely to try out these behaviors as well. This is because they have learned through observation that gambling, smoking pot, and drinking achieved a positive result. In the absence of other healthier examples, it would seem those activities were good ways to relax, have fun, and reduce stress. This can be attributed to social learning.

The social learning theory advanced by Albert Bandura, (1977) is based on the ideal that adolescence form their beliefs about anti-social from their role models in the environment who are significant owners in life especially relatives, teachers, parents, close friends among others. It asserts the adolescent involvement with the substance using role models is likely to have three consequential effects, beginning with an observation and introduction of substance specific behaviors followed by social reinforcement for early substance use. This culminates into an adolescent's positive social and psychological consequence for future use.

Individuals who have adequate coping skills and high self-esteem are able to drink at socially acceptable levels and to develop friendship with others who also avoid alcohol abuse. Those with poor coping skills in general for dealing with life problems may turn to alcohol and drugs to reduce tension, escape from problems and feel better. Secondary indications of the environment are associated with the primary stimuli of adult's drug experience. This includes not only physical aspects of the environment but also the addict's lifestyle (NACADA, 2006).

The Theorist believes that a person learns by observing what others do. Through this one cognitively represents the behavior of others and then possibly adopts this behavior (Albert, 1977). This theory is relevant to this study because through observation and internalization adolescents learn.

\subsection{Conceptual Framework}

\subsubsection{Concept Of Demarketing}

The concept of demarketing involves decreasing the consumption of a product (Christine 2006), the demarketing is that aspect of marketing that deals with discouraging customers in general or a certain class. The development of a marketing orientation specifically to this new marketing environment is the basis of the concept of demarketing. This concept maintains that the marketer's task is to shape demand to conform to long-term objectives. Demarketing as an efforts aimed at discouraging (not destroying) the demand for a product which (1) a firm cannot supply in large-enough quantities, or (2) 
does not want to supply in a certain region where the high costs of distribution or promotion allow only a too little profit margin (Business dictionary). Common demarketing strategies include higher prices, scaled-down advertising, and product redesign. According to Websters dictionary (1828), demarketing is the use of advertising to decrease demand for a product that is in short supply. The All Business dictionary (2010) defines demarketing as, marketers attempt to reduce the demand for a product when the demand for the product is greater than the manufacturer's ability to produce it.

Demarketing may be considered as un-selling or marketing in reverse, which includes general and selective demarketing. Marketing as a concept, philosophy, and a practice has moved beyond being an activity of business organizations, and has occupied a distinct place in the economic life of any society. The functions of marketing have characteristically emphasized the task of creating and maintaining demand in an environment of abundance. However, recent changes in the business environment have focused attention on a wider range of marketing tasks which include reducing overall demand on Demarketing.

Demarketing activities discourage demand, this stands in sharp contrast to the objectives of marketing which create utility and enhance exchange. According to Bradley \& Blythe (2014) demarketing is a deliberate attempt by marketers to reduce demand for a product by using the same tools and techniques as are normally used to increase demand. Wall (2007), asserted demarketing as a use for marketing hypotheses to convince customers to change their attitudes and behaviours regarding certain products and services, while Robert \& Moore (2005) asserted that demarketing is the act of discouraging consumption or use of specific product or service.

\section{REASONS FOR DEMARKETING}

According to Emeli (2020), demarketing is an efforts made or steps taken by companies to reduce or discourage demands for a product generally. Reasons for demarketing are;

1. When demands is more than supply

2. Where company should reserve resources

3. Poor or absent distribution chain

4. When the price of selling in a particular location is extremely high

5. Save consumers from health complications.

\subsection{Demarketing Strategies}

Demarketing strategies may differ when being used by a private firm versus a government entity. Social marketing strategies have been widely implemented to demarket products or services that are perceived to be harmful or costly to society. The social marketing strategy are stating the goals and objectives.

The following are the demarketing strategies;

1. Price discriminating demarketing: Price discriminating firms may create transaction costs deliberately to discourage consumers from seeking the lowest price. Busy consumers pay higher prices, whereas those with small transaction costs pay lower prices. For example, some retailers hold "3-hour sales" from 8 to 11 Saturday morning. Consumers who get to the store before 11:00 am pay lower prices but incur the inconvenience of early morning shopping. Busy consumers who want a time-convenient product may pay a higher price for that product, so a firm may make the more convenient product more expensive.

2. Bait and switch demarketing: The bait-and-switch demarketing strategy is when a firm advertises one product in such a way that the intention is not that the consumers buy that product, but that they buy a more profitable product in its place.

3. Stock outage demarketing: Another known demarketing strategy is stock outage demarketing, where a firm actually plans a stock outage. Stock outages frustrate consumers, but stores often offer rain checks that guarantee delivery at a future date. Deliberate stock outages help stores 
charge higher prices and earn higher profits. The possibility of a stock outage in one store makes customers more eager to buy when the other store has the product in stock.

4. Crowding costs Demarketing: Crowding cost demarketing is a strategy implemented on "Black Friday" when crowds will deter many consumers from purchasing a product at a lower price. Retail stores, hotels, and airlines have limited capacities. A low price usually attracts large numbers of shoppers, so customers must hunt for space in crowded parking lots and stand in long checkout lines. Businesses may deliberately accept capacity constraints, recognizing that some customers would trade the higher prices for reduced crowding.

\subsection{Types of Demarketing}

Rudaina (2014), identify three types of Demarketing strategies, they are;

1. General Demarketing: This is required when a company wants to shrink the level of total demand

2. Selective Demarketing: This is required when a company wants to discourage the demand comingfrom certain customer levels.

3. Ostensible Demarketing: This involves the appearance of trying to discourage demand as a devicefor actually increasing. This strategy is seen implemented in organizationslooking towardsdecreasing the demand on a specific product for a limited time while with the intention of increasingits price in the future and create the image of missing the product in the market which will create animpression in the customer's mind regarding the product quality making it valuable and worthy to behad.

\section{ViCES AMONG THE YOUTH IN TERTIARY InSTITUTION}

In Nigeria tertiary institution there are different social vices that could be found among the youths, such as,

1. Gambling: Gambling is the wagering of money or something of value on an event with an uncertain outcome, with the primary intent of winning money or material goods. It is a contest where a player bets on the result of an event. The bet is generally in the form of money. The outcome is dependent on the predictability of the event. The rules and the amount of money bet are decided on before the events happens.

2. Prostitution and sex abuse: some takes Aphrodisiacs, aphrodisiacsare substances that arouse sexual desire or increase a person's capacity for sexual activities (Greenberg, Bruess \& Haffner, 2003). It is also known as libido boosters and popularly called 'manpower in the streets, 'qurantaashi' in the northern part of the country, and 'aleko' in south west Nigeria. The agents enhance the sexual drive performance and lead to greater sexual satisfaction. Some of the students involve in prostitution for money making, some to pay their schools fees and general maintenance. Some youth involve in sex abuse like rapping. When they are arouse maybe after taking libido boosters they will like to go in for an action.

3. Gluttony: This is over indulgence and over consumption of food, drink or wealth items. Gluttony is a situation in which people eat and drink more than they need. When a youth is addicted to this lifestyle, he will always want to satisfy his/her self and this may lead to stealing.

4. Smoking: This is common among youth, they take Nicotine, and nicotine is a poisonous alkaloid derived from tobacco plant. It is responsible for the dependence of regular smokers on cigarettes. (Elizabeth \& Martin, 2007). Nicotine is in tar, cigars, cigarettes, tobacco and traditional snuff. A small dose of nicotine has a stimulating effect on the autonomic nervous system.

5. Using drugs: According to Dorwick and Maline (2007), Drug is defined as any natural or artificial substance, other than food that by its chemical or physical nature alters structures or functions in the living organization. Some these drugs has their own good part but the youth uses them for a negative ways that satisfied them, they are classified under stimulants, narcotics, cannabis and depressants. Examples of those drugs are, caffeine, cocaine, nicotine, amphetamine, Heroin, Opium, Morphine, Codeine, Tramadol, marijuana, hashish, bhang, Alcohol, Barbiturate, Tranquilizer and Rohypnol and libido boosters. 
6. Social networking: The Internet is a very huge network, it can be regarded as the network of all networks. Networking is a set-up that links lots of computers together worldwide, creating a network that computers can communicate with each other. Andrew (2005) opined that the internet is a global highway for information decimation; it is the international collection of computer networks. Theinternet has a countless benefit on the life of student. It helps in every aspect $\mathrm{s}$ of his/her life. The influence of social media on students is alarming and doing more harm than good. The Social Networking sites such as Youtube, Twitter, Instagram, Whatsup and Facebook have become widespread amongst the students of the tertiary institution across the globe; it is so because of the charming of their features. Facebook is the most widely held social networking website amid the others. A social media network is only an electronic links amongst its users which turned out to bea habit for students, youngsters, and even the grown person. The influence of social media on students is alarming. Social media is uses mobile and web based technology to make vastly collaborating platforms in which people in a community share, co-create, discuss and modifies user's generated content (Kietzmannn, 2012), students give much attention to their education than the social media, but regrettably the social networking sites distress education severely. It has become a habit to students in schools to use the internet at alltime due to its eye catching features. There is unconventionality, interruption and divided attention amid social networking happenings and their academic effort.

7. Cultism: cultism is the practices or activities of a group of people who have extreme beliefs that are considered severe. It is a social crime which is rampant within the school system. They exist by using drugs and using dangerous weapons to fight their enemies or opposition.

8. Indecent dressing: Indecent dressing can be defined as the wearing of cloths that are not appropriate for a particular occasion or situation. It means deliberate exposure of one's body to the public, which is contrary to the acceptance norms and values of the society. The youth learn all these from the internet, watching movies and also from their peer group.

\subsection{Suggestions}

The following suggestions will be useful,

1. The government should constantly do wide broadcast by condemning the dangerous products that the youth uses.

2. Regular seminars and conferences should be organized by the government with the trade unions condemning the productions and sales of such products.

3. Parents should be a role model and their lives should reflect a good example to the youth.

4. Parents should be at a close watch on their children/wards

5. The marketers should be ready at all time to stop marketing any products that encourages vices.

6. Manufacturers should determine to put age limit to purchase to some of their products which the youth can used, like gun which the cultists use.

7. Drugs that are important for medications should be strictly given to hospitals or where it is needed and should not be on sale for public purchases.

8. Any products discovered that are used otherwise should be frown at by the marketers and producers, and a strict demarketing strategies should use immediately

\section{CONClusion}

Demarketing discourages demand for a product. This is in contrast to the objective of marketing. Conventionally marketing seeks to grow the consumer base and boost the demand for a product or service. This then follows that demarketing would adapt the marketing mix structure to serve the opposite purpose of reducing the consumer base and discouraging demand for a product and service. Demarketing is necessary to curb the sales ofinstitutions are fed up with the habits and manners of consuming vice products which affect individuals, community and environment negatively. These consuming habits and patterns are becoming a source of concern to all administrators of tertiary institutions, working agencies in public health-related field, infrastructure, and others, and these agencies try in a different way to have campaigns to discourage the intake of vice products. The 
schools, administrators, government and their agencies, parents, individuals like the politicians, manufactures, organizations and people that matters must rise up now to fight the spread of this vices among the youths, these youths are our future and the future of our great nation.

\section{REFERENCES}

[1] Albert. B. (1977). Social learning theory.www.wikipedia.com. Retrieved 2021.

[2] All business dictionary (2010). Demarketing Wileypublishinglnc, Indianapolis, Indina. https://www.your dictionary.com. Retrieved 2021

[3] Bradley, N. \& Blythe J. (2014). Demarketing. https//www.amazon.com.>demakerting. Retrieved 2021.

[4] Christine, L.B. (2006). Demarketing as a tool for managing visitor demand in nationalparks- An Australian case study, thesis submitted in partial fulfilment of the requirements for the degree of master of Arts in Tourism,. Retrieved 2021.

[5] Demarketing, www. Businessdictionary.com. Retrieved, 2021.

[6] Demarketing (2018). https://www.marketing91 .com/ demarketing/ retrieved 2021.

[7] Emeli, F. (2020). Demarketing: All you need to know (+ case study). Retrieved from https//businessyield.com.marketing 2021.

[8] Kabir, H.K. (2008). Youth and National development: Opportunities and challenges. Conference paper presented in a 2-day international conference on Nigeria youth andNational development, Nigeria, https// www. researchgate. net> publication. Retrieved.2021.

[9] Nelson.P.S. (2019). Social vices, the way out.https// www. scribd. com> document, retrieved 2021.

[10] Nelson. S. (2018). Social vices, the way out. https:// www. scribd. com/document/SOCIAL -VICES-THE-WAY-OUT-SV-TWO.Retrie

[11] Oye, N. D, Ibrahim. I. (2016). The Vices of Social Media on Students Success at the Adamawa State Polytechnic, Yola - Nigeria. International Journal of ComputerScience \& Information Technology (IJCSIT) Vol 8, No 4, August2016.01:10.512 l/ijcsit.2016.840323

[12] Philips, K \& Sidney, L. (2019). What is demarketing, types of demarketing and examples. Retrieved from https://www.marketing91.com.

[13] Robert. D. \& Moore, P. (2005). Demarketing, https//en.m.wikipedia.org. Retrieved 2021.

[14] Rudaina, R.Y. (2014). The impact of ostensible demarketing strategy on improving product. Retrieved 2021.

[15] Samydai, M. (2017). The role of demarketing in reducing electricity demand.. Tertiary education, World Bank (2017). Wikipedia, www.google. Com, retrieved 2019.

[16] Shilpa.D., Pise.A., Sreedhar.D.,Udupa, N (2007). .Demarketing of injurious consumption: An Indian scenario. https // www. researchgate. net> publication. Retrieved, 2021.

[17] Wall, D. (2007). Defflarto, www.google.comWall (2007), Retrieved 2021.

[18] Websters Dictionary (1828). Demarketing Websters dictionary 1828.com Retrieved 2021.

Citation: $\operatorname{Dr}$ (Mrs) Olowe, Modupe Oluwatoyin, Ayeni, Olapade Grace. " Demarketing: A Tool for Managing Youth Vices in Tertiary Institution for National Development" International Journal of Humanities Social Sciences and Education (IJHSSE), vol 8, no. 6, 2021, pp. 1-6. doi: https://doi.org/10.20431/23490381.0806001 .

Copyright: () 2021 Authors. This is an open-access article distributed under the terms of the Creative Commons Attribution License, which permits unrestricted use, distribution, and reproduction in any medium, provided the original author and source are credited. 